Mulyono, et al. 2021

\title{
FERMENTASI JERAMI PADI MENGGUNAKAN Trichoderma AA1 DAN PENGARUHNYA TERHADAP SUHU, pH DAN NILAI KECERNAAN IN VITRO
}

\author{
Ali Mursyid Wahyu Mulyono'), Ahimsa Kandi Sariri²), Desyanto1) \\ 1) Program Studi Peternakan, Fakultas Pertanian, Universitas Veteran Bangun Nusantara \\ Jl. Letjen Sujono Humardani No. 1, Sukoharjo Tel. 0271-593156, Fax 0271-591065, \\ email: alimursyid wm@yahoo.com \\ 2) Penulis korespondensi, email: ak sariri@ymail.com
}

\begin{abstract}
Abstrak
Penelitian ini bertujuan untuk mengetahui pengaruh lama fermentasi jerami padi menggunakan Trichoderma AA1 terhadap suhu, $\mathrm{pH}$ dan nilai kecernaan jerami padi fermentasi Penelitian menggunakan Rancangan Acak Lengkap pola searah dengan macam perlakuan berupa lama fermentasi yang terdiri dari 0, 7, 14 dan 21 hari. Masing-masing macam perlakuan diulang 4 kali. Larutan Trichoderma AA1 disiapkan dengan menginkubasikan $2 \mathrm{~g}$ inokulum Trichoderma AA1 dalam $200 \mathrm{ml}$ larutan yang mengandung $2 \mathrm{~g}$ molases pada rotary shaker selama 24 jam. Medium disiapkan dengan mencampurkan $1 \mathrm{~kg}$ jerami kering cacah dengan $30 \mathrm{~g}$ dedak halus, $20 \mathrm{~g}\left(\mathrm{NH}_{4}\right)_{2} \mathrm{SO}_{4}$ dan aquades hingga kadar air menjadi $65 \%$. Fermentasi dilakukan dengan cara mencampurkan larutan Trichoderma AA1 dan medium. Materi fermentasi dimasukkan ke dalam bioreaktor aerob dan selanjutnya diinkubasian selama waktu 21 hari. Pengukuran suhu dan $\mathrm{pH}$ sekaligus pengambilan sampel jerami padi fermentasi dilakukan pada hari ke-0, 7, 14 dan 21. Sampel dikeringkan dengan suhu $70^{\circ} \mathrm{C}$ selama $12 \mathrm{jam}$. Pengukuran kecernaan in vitro menggunakan metode gastest. Hasil penelitian menunjukkan bahwa lama fermentasi berpengaruh sangat nyata $(P \leq 0,01)$ terhadap peningkatan suhu dan $\mathrm{pH}$ fermentasi. Suhu dan $\mathrm{pH}$ tertinggi terjadi pada fermentasi 7 hari. Dari variabel kecernaan in vitro bahan kering (KcBK) dan bahan organik (KcBO) menunjukkan nilai yang tidak nyata $(P>0,05)$ berbeda. Penelitian disimpulkan bahwa waktu terbaik fermentasi jerami padi menggunakan Trichoderma AA1 adalah 7 hari, namun belum berpengaruh signifikan terhadap nilai KcBK dan KcBO.
\end{abstract}

Kata Kunci : Jerami padi, Trichoderma AA1, Kecernaan in vitro.

\section{(Paddy Straw Fermentation using Trichoderma AA1 and their Effect on Temperature, $\mathrm{pH}$ and In Vitro Digestibility)}

\begin{abstract}
This study aims to determine the effect of the fermentation time of paddy straw using Trichoderma AA1 on temperature, $\mathrm{pH}$ and digestibility value of fermented paddy straw. This study used a a one-way completely randomized design. The treatment is the length of fermentation consisting of 0, 7, 14 and 21 days. Each treatment was repeated 4 times. Trichoderma AA1 solution was prepared by incubating of $2 \mathrm{~g}$ Trichoderma AA1 inoculum in $200 \mathrm{ml}$ of a solution containing $2 \mathrm{~g}$ of molasses on a rotary shaker for 24 hours. The medium was prepared by mixing of $1 \mathrm{~kg}$ chopped dry paddy straw with $30 \mathrm{~g}$ of rice bran, $20 \mathrm{~g}$ (NH4)2SO4 and some aquades until the water content became $65 \%$. Fermentation is done by mixing a solution of Trichoderma AA1 and medium. The fermentation culture is placed into an aerobic bioreactor and then incubated for 21 days. Measurement of temperature and $\mathrm{pH}$ as well as sampling of fermented paddy straw was carried out on days 0, 7, 14 and 21. The samples were dried at $700 \mathrm{C}$ for 12 hours. In vitro digestibility measurement using the gas-test method. The results showed that the length of time of fermentation had a highly significant effect $(P \leq 0.01)$ on the increase in temperature and $\mathrm{pH}$ of fermentation. Peak of temperature and $\mathrm{pH}$ occurred at 7 days of fermentation. The in vitro digestibility of dry matter (IVDDM) and in vitro digestibility of organic matter (IVDOM) showed non-significantly difference $(P>0.05)$. This study concluded that the best time for fermenting paddy straw using Trichoderma AA1 was 7 days, but it not-significantly affect on the IDDM and IDOM.
\end{abstract}

Key words: Paddy straw, Trichoderma AA1, In vitro digestibility. 


\section{PENDAHULUAN}

Jerami padi merupakan salah satu produk samping pertanian yang tersedia cukup melimpah. produksi padi tahun 2010 di perkirakan sebesar 66,41 juta ton gabah kering giling dan produksi tahun 2011 di perkirakan sebesar 67,31 juta ton gabah kering giling (BPS, 2011). Rasio produksi gabah dan jerami basah sebesar 2:3, sehingga pada tahun 2010 dihasilkan jerami padi 99,615 juta ton jerami basah pertahun dan di perkirakan pada tahun 2011 menjadi 100,965 juta ton jerami basah per tahun.

Pada sisi lain, jerami padi tergolong bahan pakan yang berkualitas rendah, karena kandungan nitrogen rendah sementara kandungan serat kasarnya tinggi (Tang et al., 2008 dalam Suryapratama dan Suhartati, 2012). Kandungan serat kasar jerami padi sebesar $21,9 \%$ yang hampir semuanya adalah senyawa selulosa, sementara kandungan protein kasar hanya 7,4\% (Mulyono, 2010).

Selulosa merupakan senyawa khas penyusun dinding sel tanaman yang tidak dapat dicerna oleh enzim pencernaan unggas. Akibatnya dinding sel tetap utuh dan isi sel yang banyak mengandung nutrien tetap terlindungi ( $\mathrm{Li}$ et al., 2004; Hetland et al., 2004). Salah satu cara untuk merombak selulosa sekaligus meningkatkan kandungan protein jerami padi adalah dengan perlakuan fermentasi. Perombakan selulosa mengakibatkan dinding sel terdegradasi sehingga nutrien isi sel terbebaskan ( $\mathrm{Li}$ et al., 2004). Selanjutnya nutrien isi sel dapat dicerna oleh enzim pencernaan unggas (Hetland et al., 2004).

Fementasi pada suatu bahan dapat meningkatkan kandungan protein, perbaikan kecernaan serta terbentuknya berbagai asam amino, enzim dan vitamin (Mulyono et al., 2009a). Fermentasi pada bahan kaya serat kasar sangat tergantung keberadaan enzim selulase yang diproduksi oleh mikroba selulolitik. Enzim ini bertanggung jawab pada perombakan selulosa menjadi produk yang mudah diabsorbsi sel. Pusat perhatian mikrobia pendegradasi limbah pertanian yang banyak mengandung selulosa, saat ini terfokus pada fungi. Sebagian besar fungi merupakan organisme yang dianggap lebih kuat dalam menghasilkan enzim ekstra seluler, termasuk selulase (Gianfreda dan Rao, 2004). Fungi yang mempunyai aktivitas selulolitik tinggi salah satu diantaranya adalah Trichoderma. Trichoderma $A A 1$ adalah sebuah mirkoba mutan resisten terhadap represi katabolit (Mulyono et al., 2007), sehingga sangat potensial di gunakan utuk fermentasi pada substrat yang kaya selulosa seperti jerami padi.

Tujuan penelitian ini adalah untuk mengetahui pengaruh lama fermentasi jerami padi menggunakan Trichoderma AA1 terhadap suhu, $\mathrm{pH}$ dan nilai kecernaan jerami fermentasi.

\section{BAHAN DAN METODE}

\subsection{Mikroba.}

Mikroba yang digunakan adalah Inokulum Trichoderma AA1 merek TrichoStar dalam bentuk serbuk produksi Fakultas Pertanian, Universitas Veteran Bangun Nusantara, Sukoharjo.

\subsection{Medium fermentasi.}

Substrat berupa jerami padi yang di dapatkan dari petani di Kecamatan Selogiri, Kabupaten Wonogiri. Medium lain yang digunakan meliputi ammonium sulfat $\left(\mathrm{NH}_{4}\right)_{2}$ $\mathrm{SO}_{4}$, molase dan dedak halus.

\subsection{Preparasi mikroba dan medium.}

Dua gram molase dilarutkan dalam 200 $\mathrm{ml}$ aquades mendidih. Setelah larutan molases dingin, ditambahkan $2 \mathrm{~g}$ inokulum 
Trichoderma AA1, kemudian diinkubasikan selama 24 jam menggunakan rotary shaker. Larutan Trichoderma AA1 siap digunakan.

Jerami padi kering matahari dicacah dengan panjang $3-5 \mathrm{~cm}$. Satu $\mathrm{kg}$ jerami padi kering cacah ditambah dengan sejumlah aquades hingga kadar air menjadi $65 \%$. Jerami padi basah ini kemudian ditambah dengan $30 \mathrm{~g}$ dedak halus, $20 \mathrm{~g}$ $\left(\mathrm{NH}_{4}\right)_{2} \mathrm{SO}_{4}$, kemudian dicampurkan secara merata. Medium padat siap digunakan.

\subsection{Rancangan Percobaan.}

Percobaan menggunakan Rancangan Acak Lengkap (RAL) Pola Searah dengan 4 macam perlakuan. Masing-masing perlakuan digunakan 4 unit ulangan. Perlakuan berupa lama fermentasi yang meliputi 0, 7, 14 dan 21 hari. Analisis statistik yang digunakan adalah Analisis Variansi Pola Searah dengan uji lanjut lanjut duncan's multiple range test (DMRT) (Mulyono, 2011).

\subsection{Percobaan fermentasi.}

Larutan Trichoderma AA1 dan medium yang telah dipersiapkan sebelumnya dicampur secara merata kemudian dimasukkan ke dalam bioreaktor dari ember plastik dan ditutup dengan kain. Inkubasi dilakukan dalam waktu 21 hari. Pengamatan suhu dan $\mathrm{pH}$ dilakukan setiap hari pada jam yang sama. Pengambilan sampel jerami padi fermentasi sebanyak 20 g dilakukan pada hari ke-0, 7, 14 dan 21. Sampel dikeringkan dengan suhu $70^{\circ} \mathrm{C}$ selama 12 jam.

\subsection{Variable pengamatan.}

Variabel yang diamati meliputi suhu, derajat keasaman $(\mathrm{pH})$, dan kecernaan jerami padi fermentasi. $\mathrm{pH}$ diukur menggunakan kertas indikator $\mathrm{pH}$. Suhu diukur menggunakan termometer yang ada di dalam bioreaktor. Kecernaan jerami padi fermentasi diukur menggunakan metode gas-test.

\section{HASIL DAN PEMBAHASAN}

Hasil pengukuran jerami padi fermentasi dengan perlakuan lama fermentasi disajikan pada Tabel 1.

\section{Perubahan suhu selama fermentasi.}

Berdasarkan analisis variansi pola searah menunjukan bahwa fermentasi jerami padi menggunakan Trichoderma AA1 mengakibatkan peningkatan secara nyata terhadap suhu fermentasi. Sajian grafis perubahan suhu fermentasi dapat dilihat pada Gambar 1.

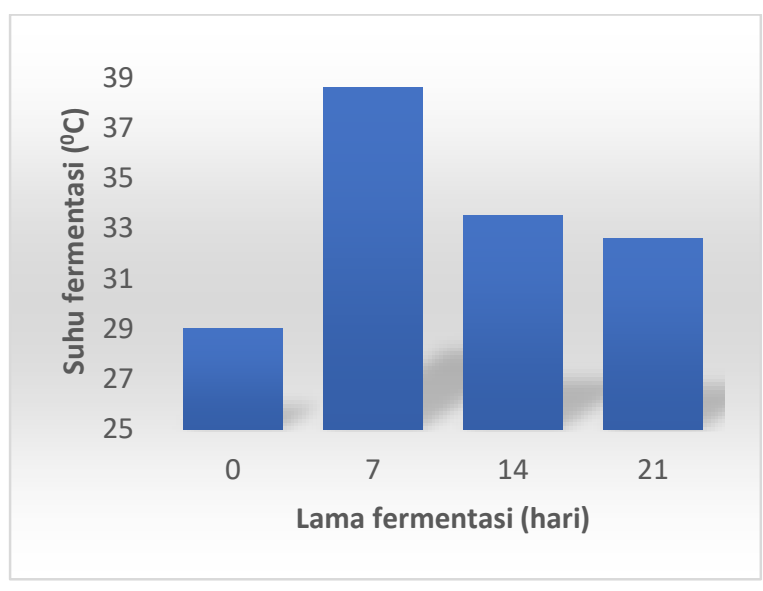

Gambar 1. Kurva perubahan suhu fermentasi pada berbagai perlakuan lama fermentasi.

Pada fermentasi 7 hari, rerata suhu meningkat sangat nyata $(P \leq 0,01)$ sebesar $9,6^{\circ} \mathrm{C}$ (dari $29^{\circ} \mathrm{C}$ menjadi $38,6^{\circ} \mathrm{C}$. Ketika fermentasi dilanjutkan menuju 14 hari terjadi penurunan nyata $(P \leq 0,05)$ sebesar $5,1^{\circ} \mathrm{C}$. Namun suhu fermentasi pada lama fermentasi 14 hari ini secara nyata $(P \leq 0,05)$ masih lebih tinggi dibandingkan dengan suhu fermentasi hari ke-0 (kontrol). 
Tabel 1. Rerata suhu, $\mathrm{pH}, \mathrm{KcBK}$, dan $\mathrm{KcBO}$ jerami fermentasi dari berbagai perlakuan lama fermentasi

\begin{tabular}{|c|c|c|c|c|}
\hline \multirow[b]{2}{*}{ Variabel } & \multicolumn{4}{|c|}{ Lama fermentasi (hari) } \\
\hline & 0 & 7 & 14 & 21 \\
\hline Suhu $\left({ }^{0} \mathrm{C}\right)$ & $29,0^{a}$ & $38,6^{c}$ & $33,5^{b}$ & $32,6^{b}$ \\
\hline $\mathrm{pH}$ (skala 1-14) & $7,0^{\text {a }}$ & $7,9^{c}$ & $7,3^{b}$ & 7,2 ab \\
\hline Kecernaan Bahan Kering (KcBK, \%) ${ }^{\text {ns }}$ & 24,8 & 20,3 & 18,9 & 18,7 \\
\hline $\begin{array}{l}\text { Kecernaan Bahan Organik (KcBO, \%) } \\
\text { ns }\end{array}$ & 27,9 & 21,0 & 22,9 & 20,37 \\
\hline
\end{tabular}

Fenomena ini menunjukan proses fermentasi jerami padi menggunakan Trichoderma AA1 berjalan dengan baik. Proses fermentasi oleh mikroba akan menghasilkan panas sebagai sebuah tanda kalau mikroba melakukan metabolisme. Mekanisme yang terjadi adalah Trichoderma AA1 mensekresikan enzim selulase untuk mendegradasi selulosa pada jerami padi, yang kemudian ditransformasikan menjadi senyawa sederhana (glukosa) yang siap diabsorpsi sel mikroba. Di dalam sel mikroba, glukosa akan digunakan untuk proses metabolisme sel yang menghasilkan energi biologi (ATP) maupun panas (Mulyono, 2008b).

Penurunan suhu pada lama fermentasi 14 dan 21 hari diduga karena kemampuan mikroba dalam memecah selulosa dan nutrien lain sudah menurun, sehingga asupan nutrien untuk sel mikroba juga berkurang (Mulyono et al., 2007). Mulyono (2008a) menyatakan bahwa proses fermentasi dapat berjalan baik apabila di dalam medium tersedia semua nutrien yang dibutuhkan mikroba,

Semakin lama proses fermentasi berlangsung akan meningkatkan akumulasi panas yang dihasilkan dari metabolisme mikroba. Hal ini berakibat kondisi optimum lingkungan fermentasi bagi mikroba tidak terpenuhi (Mulyono et al., 2009b).
Lama fermentasi jerami padi selama 7 hari terlihat paling optimum. Pada hari itu tercapai puncak suhu fermentasi. Hasil ini sesuai dengan Supriyati et al. (2010) yang menyatakan bahwa lama fermentasi jerami padi yang optimal adalah 7 sampai 11 hari pada suhu ruang dan kondisi aerob. Pada hari ke 14 hingga hari ke 21 menunjukan penurunan suhu yang tidak signifikan, tapi proses fermentasi masih berlangsung.

\section{Perubahan pH selama fermentasi.}

Hasil analisis variansi pola searah menunjukan bahwa fermentasi jerami padi menggunakan Trichoderma AA1 mengakibatkan peningkatan secara nyata $\mathrm{pH}$ fermentasi. Sajian grafis perubahan $\mathrm{pH}$ fermentasi dapat dilihat pada Gambar 2.

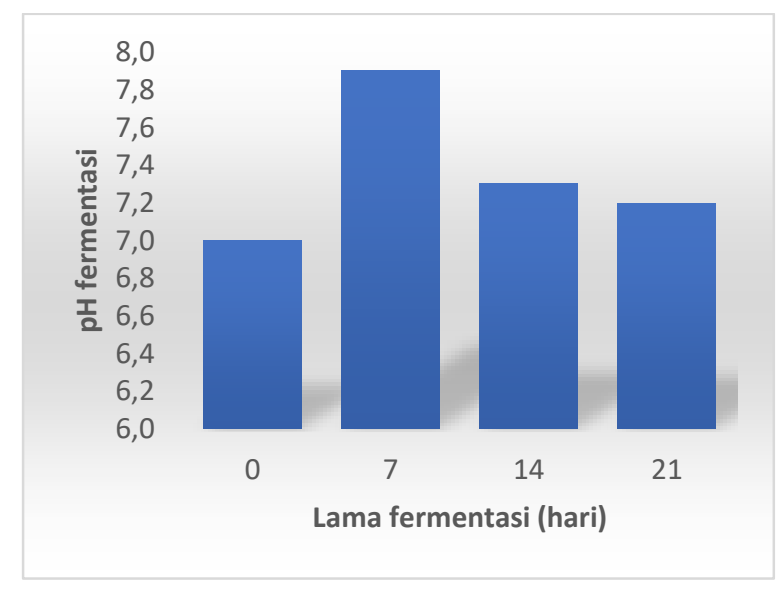

Gambar 2. Kurva perubahan $\mathrm{pH}$ fermentasi pada berbagai perlakuan lama fermentasi. 
Pola perubahan $\mathrm{pH}$ fermentasi jerami padi mirip dengan perubahan suhu. Fermentasi 7 hari meningkat sangat nyata $(P \leq 0,01)$. Ketika lama fermentasi ditambah menjadi 14 hari terjadi penurunan $\mathrm{pH}$ secara nyata $(P \leq 0,05)$. Ketika lama fermentasi ditambah lagi menjadi 21 hari, $\mathrm{pH}$ menurun tidak nyata $(\mathrm{P}>0,05)$. Meskipun terjadi penurunan $\mathrm{pH}$ pada fermentasi 14 dan 21 hari, akan tetapi nilainya masih lebih tinggi secara nyata $(P \leq 0,05)$. Miripnya pola perubahan suhu dan $\mathrm{pH}$ ini selaras dengan pendapat Fardiaz (1998) bahwa jika suhu pertumbuhan naik, maka $\mathrm{pH}$ optimum untuk pertumbuhan juga naik.

Puncak nilai suhu dan $\mathrm{pH}$ terjadi pada fermentasi 7 hari. Hal ini menandakan bahwa dilihat dari variabel suhu dan $\mathrm{pH}$ maka lama fermentasi optimum pada fermentasi jerami padi menggunakan Trichoderma AA1 adalah 7 hari. Fermentasi pada hari-hari pasca puncak $\mathrm{pH}$ kemungkinan disebabkan aktifitas enzim selulase mulai melambat dalam memecah selulosa jerami padi. Dapat juga penurunan $\mathrm{pH}$ pasca nilai puncak disebabkan akumulasi dari sekresi asam organik seperti asam asetat, sitrat dan laktat, serta terkonsumsinya garam amonium oleh mikroba (Mulyono et al., 2009b).

\section{Kecernaan bahan kering (KcBK) jerami padi fermentasi.}

KcBK diukur untuk mengetahui seberapa besar bahan kering yang dapat diserap tubuh dari sejumlah bahan kering yang dikonsumsi ternak (McDonald,2002). Secara in vitro, KcBK diketahui dengan mengukur jumlah bahan kering pakan yang diuji dikurangi jumlah bahan kering residu pakan yang diuji.

KcBK jerami padi fermentasi dari berbagai lama fermentasi pada penelitian ini secara statistik berbeda tidak nyata (Tabel 1). Pola grafis pengaruh lama fermentasi terhadap KcBK dapat dilihat pada Gambar 3.

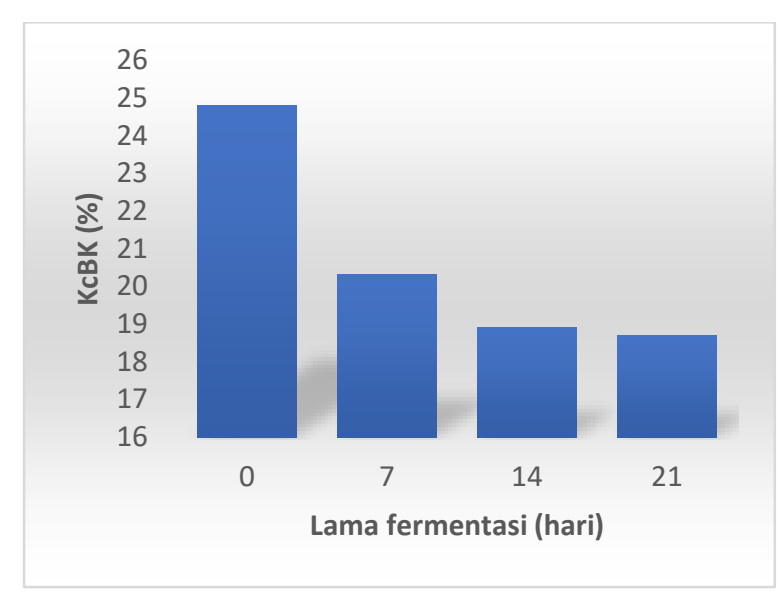

Gambar 3. Kurva perubahan nilai kecernaan bahan kering (KcBK) jerami fermentasi pada berbagai perlakuan lama fermentasi.

Meskipun perubahan nilai KcBK jerami fermentasi secara statistik tidak nyata $(P>0,05)$, namun dengan menggunakan $\alpha=0,1$ pada analisis statistik maka terlihat adanya kecenderungan penurunan KcBK $(P \leq 0,1)$. Artinya seperti terlihat pada Gambar 3 bahwa terjadi kecenderungan penurunan nilai KcBK jerami fermentasi pada lama fermentasi 7 dan 14 hari, setelah itu nilai KcBK konstan pada lama fermentasi 21 hari.

Fenomena ini diduga karena kandungan lignin yang terdapat pada jerami padi. Enzim selulase yang di hasilkan Trichoderma AA1 belum bisa maksimal dalam memutus ikatan silika dan lignin, sehingga struktur dinding sel relatif masih utuh. Dinding sel inilah yang menghambat terbebaskannya nutrien isi sel ( $\mathrm{Li}$ et al., 2004; Hetland et al., 2004) jerami padi untuk bisa dicerna enzim pencernaan. Anggorodi (1994) menambahkan bahwa semakin banyak serat kasar yang terkandung dalam suatu bahan pakan, akibatnya semakin rendah daya cerna bahan pakan tersebut.

Kecenderungan penurunan KcBK 
Agrisaintifika

pada fermentasi jerami padi dalam penelitian ini mungkin juga bisa disebabkan terakumulasinya $\mathrm{H}_{2} \mathrm{O}$ hasil hidrolisis nutrien substrat oleh mikroba. Air yang terlalu tinggi dalam fermentasi padat tidak baik untuk perkembagan dan pertumbuhan mikroba. Haddadin et al., (2009) dalam Gani (2013) menjelaskan bahwa kadar air pada substrat yang terlalu tinggi pada fermentasi media padat menyebabkan $\mathrm{O}_{2}$ yang terdapat pada pori-pori substrat di gantikan oleh $\mathrm{H}_{2} \mathrm{O}$ sehingga tercipta kondisi anaerob. Akibatnya difusi $\mathrm{O}_{2}$ dalam substrat berkurang dan berlanjut pada penurunan dekomposisi substrat. Kondisi anaerob tidak sesuai dengan tipikal Tricoderma AA1 yang merupakan mikroba selulolitik aerob.

\section{Kecernaan bahan organic (KcBO) jerami padi fermentasi.}

Bahan organik merupakan salah satu komponen bahan kering. Bahan organik adalah bahan kering setelah dikurangi komponen abu. KcBO jerami padi fermentasi dari berbagai lama fermentasi pada penelitian ini secara statistik berbeda tidak nyata (Tabel 1). Pola grafis pengaruh lama fermentasi terhadap KcBO dapat dilihat pada Gambar 4.

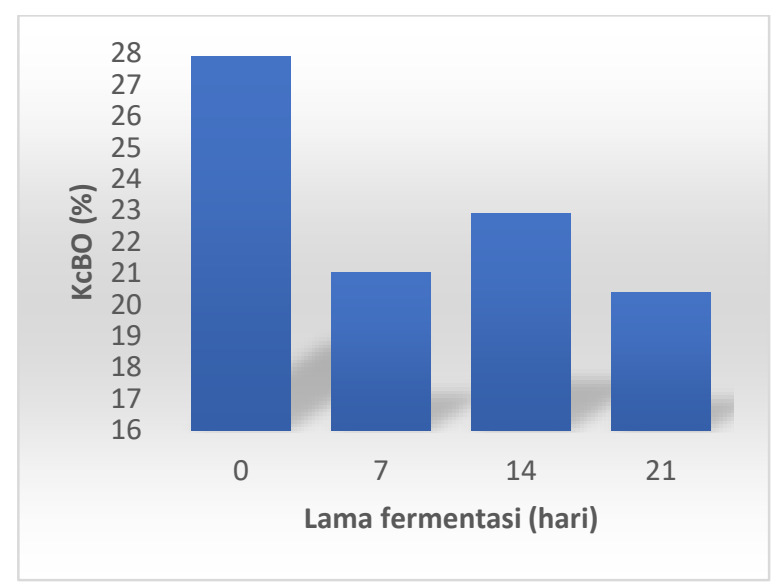

Gambar 4. Kurva perubahan nilai kecernaan bahan organik (KcBK) jerami fermentasi pada berbagai perlakuan lama fermentasi.
Pola perubahan KcBO jerami fermentasi ini mrip dengan KcBK, yakni terlihat adanya kecenderungan penurunan $\mathrm{KcBO}(\mathrm{P} \leq 0,1)$. Kecenderungan penurunan nilai KcBO jerami fermentasi terjadi pada lama fermentasi 7 hari, kemudian nilai KcBO relatif konstan pada lama fermentasi 14 dan 21 hari.

Fenomena perubahan $\mathrm{KcBO}$ ini dapat dijelaskan dengan pendekatan yang sama dengan KcBK, yakni kandungan lignin jerami padi dan terakumulasinya $\mathrm{H}_{2} \mathrm{O}$ hasil hidrolisis nutrien substrat oleh mikroba pada proses fermentasi jerami padi.

\section{KESIMPULAN}

Penelitian disimpulkan bahwa waktu terbaik fermentasi jerami padi menggunakan Trichoderma AA1 adalah 7 hari, namun belum berpengaruh signifikan terhadap nilai kecernaan bahan kering (KcBK) maupun kecernaan bahan organik (KcBO).

\section{UCAPAN TERIMA KASIH}

Terima kasih dan apresiasi disampaikan kepada Direktorat Riset dan Pengabdian kepada Masyarakat, Direktorat Jenderal Penguatan Riset dan Pengembangan, Kementerian Riset dan Pendidikan Tinggi Republik Indonesia, yang telah mendanai penelitian ini dalam program Penelitian Hibah Kompetensi, dengan kontrak nomer 015/K6/KM/SP2H/ RESEARCH_BATCH-1/2015.

\section{DAFTAR PUSTAKA}

Aggorodi, R. 1994. Ilmu makanan Ternak Umum. PT. Gramedia Pistaka Utama. Jakarta.

BPS. 2011. Badan Pusat Statistik. http://www.bps.go.id/Brs/view/id/992.

Hetland, H., M. Choct and B.Svihus. 2004. Role of insoluble non-starch polysaccharides in poultry nutrition. World's Poultry Sci Journal, 60:415422. 
Agrisaintifika

Jurnal Ilmu-Ilmu Pertanian

Vol. 5, No. 2, 2021

Mulyono, et al. 2021

Gani. R.K. 2013. Kecernaan in vitro bahan kering dan bahan organik jerami jaggung (Zea mays) yang di inokulasi dengan Trichoderma sp. pada lama inkubasi yang berbeda. Skripsi. Fakultas Peternakan, Universitas Hasanudin Makasar. Makasar.

Gianfreda, L. and M.A. Rao. 2004. Potential of extra cellular enzymes in remediation of polluted soils: a review. Enzyme Microb Tech, 35: 339-354.

Li, W.F., J.Y. Sun and Z.R. Xu. 2004. Effects of NSP degrading enzyme on in vitro digestion of barley. Asian-Aust. J. Anim. Sci., 17: 122-126.

McDonald, P., R.A. Edwards, J.F.D. Greenhalgh and C.A. Morgan. 2002. Animal Nutrition. $6^{\text {th }}$ ed. Pearson Education Ltd. Essex.

Mulyono, A.M.W. 2008a. Mutan Jamur selulitik Trichoderma sp. untuk meningkatkan kualitas onggok sebagai bahan pakan ayam broiler. Disertasi. Universitas Gadjah Mada. Yogyakarta.

Mulyono A.M.W.2008b. Biokonversi selulosa menjadi sumber energi mikrobia. Widyatama, 17: 1-8.

Mulyono A.M.W.2010. Sakarifikasi jerami padi menggunakan mutan Trichoderma AA1 dan potensi nutritif limbah yang di hasilkan untuk pakan ternak. Widyatama, 19 (2): 28-35.

Mulyono, A.M.W. 2011. Rancangan Percobaan. Kepel Press. Yogyakarta.

Mulyono A.M.W., M.N Cahyanto, Sardjono, Zuprizal dan Z. Bachruddin. 2007. Mutasi Trichoderma sp. untuk meningkatkan sekresi selulase. Media Kedokteran Hewan, 22: 68-73.

Mulyono, A.M.W., Z. Bachruddin, Zuprizal dan M.N. Cahyanto. 2009a. Nilai nutritif onggok-terfermentasi mutan Trichoderma AA1 pada ayam broiler. Media Kedokteran Hewan, 24: 165170.

Mulyono, A.M.W., M.N. Cahyanto, Zuprizal dan Z. Bachruddin. 2009b. Fermentasi onggok menggunakan mutan Trichoderma untuk produksi selulase. Agritech, 29: 53-58.

Supriyati, T. Haryanti, I-G.M. Budiarsana dan I-K. Sutama. 2010. Fermentasi jerami padi menggunakan Trichoderma viridae. Seminar Nasional Teknologi Peternakan dan Veteriner 2010. Bogor. pp: 135-143.

Suryapratama. W dan F.M. Suhartati. 2012. Fermentasi jerami padi menggunakan white rot fungi dan suplementasi Saccharomyces cerevisiae pengaruhnya terhadap kecernaan nutrien secara in vitro. Agripet, 12(2): 1-6. 